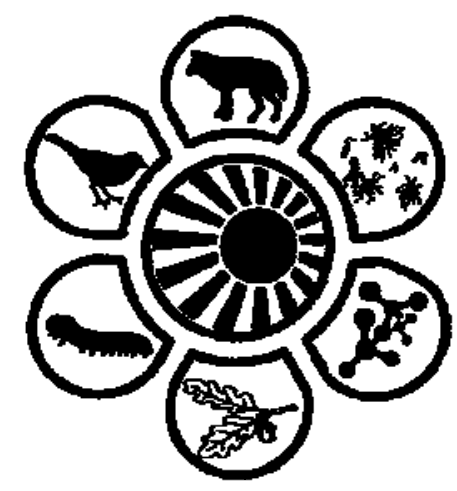

Вісник Дніпропетровського університету. Біологія, екологія.

Vìsnik Dnìpropetrovs'kogo unìversitetu. Seriâ Bìologiâ, ekologiâ

Visnyk of Dnipropetrovsk University. Biology, ecology.

Vìsn. Dnìpropetr. Unìv. Ser. Bìol. Ekol. 2015. 23(2), 129-133.

doi:10.15421/011519

ISSN 2310-0842 print

ISSN 2312-301X online

www.ecology.dp.ua

УДК 59.009:597.554.3

\title{
Вплив потужного промислового навантаження на біологічні показники плітки звичайної (Rutilus rutilus)
}

\author{
Г.О. Котовська ${ }^{1}$, Д.С. Христенко ${ }^{1}$, Р.О. Новіцький ${ }^{2}$ \\ ${ }^{1}$ Інститут рибного господарства НААН Украӥни, Київ, Украӥна \\ ${ }^{2}$ Дніпропетровський наиіональний університет імені Олеся Гончара, Дніпропетровськ, Украйна
}

\begin{abstract}
Проаналізовано віковий склад, довжину та масу тіла популяцій плітки звичайної (Rutilus rutilus L.) у водоймах із різним рівнем промислового навантаження. Кременчуцьке водосховище, яке формує понад 50\% річного промислового вилову R. rutilus в Україні, обрано як водойму з надмірним тиском промислу. Для порівняння взято акваторії природного заповідника «ДніпровськоОрільський» як приклад водного об'єкта, де тиск промислу мінімізований. Віковий ряд R. rutilus на відкритому плесі водосховищ Дніпра набагато довший, ніж у його придаткових річкових системах. Розмірно-вагові показники вікових груп $R$. rutilus $6+-10+\mathrm{y}$ водоймі з інтенсивним антропогенним навантаженням статистично достовірно нижчі, ніж в особин на природоохоронних акваторіях. Це можна пояснити наслідком селективної дії традиційного промислу ставними сітками, якими вилучаються особини з більшими темпами росту. На спрямовану елімінацію швидкоростучих особин вказали криві приростів і час настання кульмінації приросту іхтіомаси. Таким чином, потужне промислове навантаження на популяції $R$. rutilus i активне їх вилучення ставними сітками спричиняє накопичення тугорослих особин.
\end{abstract}

Ключові слова: довжина; маса; віковий склад; Кременчуцьке водосховище; Дніпровське водосховище; природний заповідник «Дніпровсько-Орільський»

\section{The impact of high commercial fishery load on biological indices of the roach (Rutilus rutilus)}

\author{
G.O. Kotovska ${ }^{1}$, D.S. Khrystenko ${ }^{1}$, R.O. Novitskiy ${ }^{2}$ \\ ${ }^{1}$ Institute of Fisheries, NAAS of Ukraine, Kyiv, Ukraine \\ ${ }^{2}$ Oles Honchar Dnipropetrovsk National University, Dnipropetrovsk, Ukraine
}

Age composition, length and weight indices of the roach populations (Rutilus rutilus L.) were analyzed and compared in water bodies with the different commercial fishery loading levels. Presence of fast-growing and slow-growing forms is inherent to cyprinid fish. In Dnieper reservoirs these forms are mixed and it is difficult to separate any one of them. It is assumed that selective elimination of fastgrowing forms by commercial fishing may cause accumulation of slow-growing forms in populations. On that ground, water bodies with different levels of commercial fishery pressure have been chosen to test this hypothesis. For instance, Kremenchuk Reservoir was selected as a water body with high level of commercial fishery load because it forms more than a half of roach commercial catching in Ukraine. On the contrary, "Dniprovsko-Orilskiy" Natural Reserve was taken as a water body where human impact is minimum. Subsequently, comparing of the basic biological features of the roach from water bodies with different commercial fishery load illustrated the value of the study. It is found that the roach age range in Kremenchuk Reservoir is much higher than in subordinate waters of the Natural Reserve fund. Namely, the roach population in Kremenchuk Reservoir consisted of seventeen age groups while in "Dniprovsko-Orilskiy" Natural Reserve it comprised ten age groups only. However, size-weight features of species under study across the age groups $6+-10+$ in water bodies with the intensive commercial fishery were statistically lower than in protected waters of the Nature Reserve. Namely, length of these age groups in Kremen-

Інститут рибного господарства НААН Украӥни, вул. Обухівська, 135, Київ, 03164, Украӥна Institute of Fisheries, NAAS of Ukraine, Obukhivska Str., 135, Kyiv, 03164, Ukraine

Tel.: +38-044-423-74-64.E-mail: khristenko@ukr.net

Дніпропетровський начіональний університет імені Олеся Гончара, пр. Гагаріна, 72, Дніпропетровськ, 49010, Україна Oles Honchar Dnipropetrovsk National University, Gagarin Ave., 72, Dnipropetrovsk, 49010, Ukraine

Tel.: +38-056-760-84-38.E-mail:zoolog@ukr.net 
chuk Reservoir was equal to $24.6-33.5 \mathrm{~cm}$, compared with $25.0-37.0 \mathrm{~cm}$ in the National Reserve. Naturally, that weight was equal to 334 957 and 340-1320 g, respectively. In general, this result does not fit into the traditional concept that the fast-growing roach should inhabit the lacustrine biocenosis of the Dnieper reservoirs. In addition, the absence of commercial fishing in waters of "Dniprovsko-Orilskiy" Natural Reserve leads to increase in number of fast-growing individuals in the population that effectively go out of predators pressure. On the other hand, high direct and indirect anthropogenic pressure cause the elimination of fast-growing individuals of the roach from population in Kremenchuk Reservoir that is proved by the curves of growth and the onset of fish-mass culmination. This study indicates that high anthropogenic pressure at present time has reached a degree which cause accumulation of stunted fish in the roach populations in Dnieper reservoirs. This is a notable effect, at least from the regulatory point of view.

Keywords: length; weight; age structure; Kremenchuk Reservoir; Dnieper Reservoir; "Dniprovsko-Orilskiy” Natural Reserve

\section{Вступ}

Моніторингові дослідження стану популяцій риб, аналіз динаміки біологічних характеристик видів актуальні питання сучасної практичної іхтіології (Kottelat and Freyhof, 2007; Movchan, 2011). Надмірне антропогенне навантаження на природні водойми спричиняє істотне погіршення умов існування не тільки раритетних, а і масових видів риб (Pakhomov et al., 2011). Упровадження нових матеріалів, технологій і способів у процес добування риби зумовили той факт, що промислове навантаження досягло таких масштабів, що здатне повністю вичерпати сировинну базу промислу. За таких умов особливе побоювання викликають запаси риб внутрішніх водойм, що зумовлює особливу увагу до їх ощадливого використання (EU intervention..., 2011). Один із таких представників аборигенної іхтіофауни для Дніпра - плітка звичайна (Rutilus rutilus L.), яка перебуває під потужним антропогенним пресом. На внутрішніх водоймах вона формує до 50\% промислового вилову не тільки у водосховищах Дніпровського каскаду (Ozinkovska et al., 2006; Rudyk-Leusska et al., 2011), а й окремих Європейських країн (Tribiloustova, 2005; EU intervention..., 2011). Цей вид також вважається улюбленим об'єктом любительського та спортивного рибальства (Novitskiy and Yarovoy, 2000; Novitskiy, 2004; EU intervention ..., 2011). В Україні плітка - охоронюваний законодавством лімітований вид, який має значний попит на споживчому ринку. У країнах $\mathrm{CC}$ R. rutilus - не $\epsilon$ лімітованим видом. Він виловлюється не цілеспрямовано, а разом з основними об'єктами промислу (EU intervention..., 2011). На 2005 рік країнами СС виловлено близько 8,7 тис. т плітки (рис. 1).

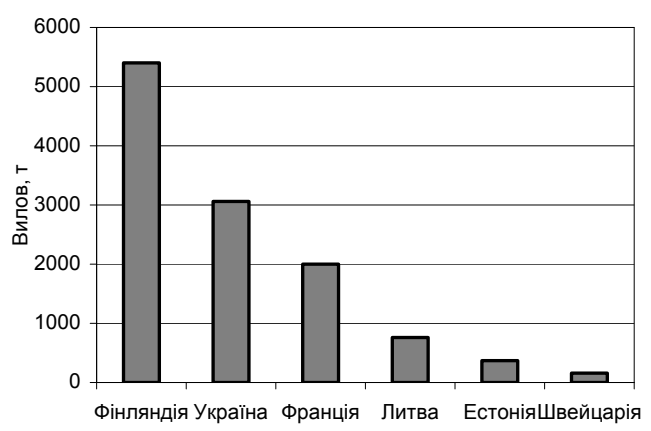

Рис. 1. Промисловий вилов $R$. rutilus окремими країнами ЄС та України (за Tribiloustova, 2005)

Основний вилов плітки припадає на Фінляндію та Францію, які загалом виловлюють понад 80\% серед країнчленів ЄС. Загальний показник вилову плітки в Україні 3060 т, що дає можливість посісти друге місце серед країн, які добувають цей вид. Тому актуальне питання сучасної промислової іхтіології - вивчення біологічних особливостей цього виду. Також не вирішеним залишається питання впливу рибальства на біологічні показники риб, які формують сучасну сировинну базу українських водойм. Для коропових риб властива наявність швидкорослих (озероподібних) (Vyatchanina, 1973; Kotovska et al., 2012; Nazarov and Kotovska, 2012) і тугорослих (річкових) форм. У водосховищах дніпровського каскаду форми змішані, відокремити якусь одну 3 них складно (Spesivyj, 2004). Можна припустити, що за рахунок селективної елімінації швидкорослих форм можливе накопичення у популяціях більш тугорослих особин.

Для перевірки цієї гіпотези ми обрали водойми 3 різним рівнем антропогенного навантаження. Якщо врахувати, що понад 50\% промислового вилову R. rutilus в Україні припадає на Кременчуцьке водосховище, воно обране як водойма, піддана потужному антропогенному навантаженню. Акваторії природного заповідника «Дніпровсько-Орільський» (верхня частина Дніпровського водосховища) розглядали як водойму, де антропогенне навантаження (У т. ч. промисел) максимально мінімізоване.

Мета роботи - оцінити основні біологічні показники R. rutilus на ділянках Дніпра з різними рівнями промислового навантаження.

\section{Матеріал і методи досліджень}

Для виконання поставлених завдань аналізували матеріали з біології плітки, відібрані на Кременчуцькому водосховищі у ході виконання науково-дослідницьких робіт на контрольно-спостережних пунктах Інституту рибного господарства НААН, а на верхній частині Дніпровського водосховища в межах природного заповідника «Дніпровсько-Орільський» - у рамках виконання науково-дослідницьких програм лабораторії біомоніторингу та охорони природи НДІ біології ДНУ імені Олеся Гончара. Іхтіологічні матеріали збирали упродовж 2006-2010 рр. за відповідними дозволами на спеціальне використання риб та інших водних живих ресурсів із правом вилучення біологічного матеріалу.

Збирання та обробку проб здійснювали за стандартними іхтіологічними та гідроекологічними методиками (Pravdin, 1966; Pakhorukov, 1980; Metodyka zbory..., 1998; Metody hydroecologichnyh..., 2006), отриманий матеріал піддали статистичній обробці. У наших дослідженнях застосовували неупереджений показник чисельності виду у водоймі - улов на 100 сітко-діб контрольного порядку сіток $(\mathrm{a}=30,36,40,45,50,55,60,65$, $70,75,80,90,100,110,120,130,140,150$ мм). На нашу думку, лише цей показник реально відображає кількість риби за віковими групами, що повністю обловлюються 
(віком від трирічок і більше). Промисел плітки на Кременчуцькому водосховищі вивчали на основі матеріалів офіційної промислової статистики та літературних даних (Ozinkovska et al., 2006).

\section{Результати досліджень та їх обговорення}

Аналізуючи біологічні показники, першочергове значення зазвичай приділяють віковому складу популяції R. rutilus і параметрам лінійного та вагового росту риб (рис. 2). Віковий ряд плітки Кременчуцького водосховища достатньо довгий, налічує сімнадцять вікових груп, що значно більше порівняно з наявними літературними відомостями для інших водойм світу. Віковий ряд плітки в акваторіях природного заповідника «Дніпровсько-Орільський» у 2002 p. (Bondarev, 2006) налічував 11 вікових груп. За даними наших досліджень, до 2010 року він скоротився до 10 вікових груп. Ця довжина вікового ряду цілком відповідає літературним відомостям про інші популяції плітки в лотичних екосистемах. Наприклад, віковий ряд цього виду в річках Лугг, Фром і Стоур у Великій Британії (Hellawell, 1972; Mann, 1973; Hickley and Dexter, 1979) та p. Варта на території Польщі (Przybylski, 1996) становить 13 років, у р. Темза у Великій Британії (Hickley and Dexter, 1979) та озері Еїлдон в Австралії (Stoessel, 2014) - 10 років, північних озерах Ірландії-6-7 років (Hayden et al., 2014). Зарубіжні дослідження показали, що темпи росту $R$. rutilus у річках були вищими, ніж у їх придаткових системах. Разом із тим, для придаткової системи природного заповідника «Дніпровсько-Орільський» спостерігається нетипова картина: лінійно-ваговий ріст вікових груп 6+- $10+$ у R. rutilus виявився статистично достовірно $(\mathrm{P}<0,05)$ вищим, ніж у особин із Кременчуцького водосховища.

Отримані результати не вкладаються у традиційні уявлення про те, що швидкоростуча плітка повинна населяти озерні біоценози відкритого плеса дніпровських водосховищ (Movchan, 2011). Ймовірно, це може бути

наслідком прямого та опосередкованого потужного антропогенного навантаження за рахунок виловлювання ставними сітками. Під час такого промислу з водойми вилучаються більш високотілі особини 3 вищими темпами росту, а тугорослі та прогонисті підпадають під дію вічкових знарядь лову пізніше. Тобто за рахунок селективної елімінації швидкоростучих особин на відкритому плесі відбулося прогресування тугоросліших особин. Так, в акваторіях природного заповідника «Дніпровсько-Орільський» промисловий лов заборонено, а на Кременчуцькому водосховищі промисловий вилов плітки в останні 10 років сягав 1,2-1,6 тис. тонн у рік. R. rutilus складає основу уловів дрібновічкових сіток i посідає друге місце у загальному валовому вилові (табл.). Для проведення повнішого аналізу та розуміння подальшого спрямування промислового навантаження розглянемо динаміку лінійного та вагового приростів $R$. rutilus у різних водоймах (рис. 3 ).

Максимальні прирости як довжини, так і маси припадають на перші роки життя, що є типовим фактом для більшості коропових риб і відповідає стратегії якнайшвидшого виходу молоді з-під пресу дрібних хижаків. У той же час кульмінація приросту іхтіомаси плітки Кременчуцького водосховища припадає на вік 6+, а в гідросистемі природного заповідника «ДніпровськоОрільський» - на $8+$.

Відомо, що промислова смертність набагато вища за природну, що показово доведено на популяціях ляща (Lammen et al., 2004). Посилена елімінація швидкоростучих особин плітки у Кременчуцькому водосховищі, яке перебуває під інтенсивним антропогенним навантаженням, спричинила накопичення більш тугорослих особин у старших вікових групах. Натомість, в акваторіях заповідника цей фактор має обмежену дію, що і спричинило накопичення швидкорослих особин. Наведені дані свідчать: антропогенне навантаження нині вже досягло такого ступеня, що здатне впливати на біологічні показники представників аборигенної іхтіофауни.

Таблиия

Показники промислового вилову (т *) деяких ресурсних видів риб Кременчуцького водосховища в 2006-2013 рр. (за статистичними даними Держрибагентства України)

\begin{tabular}{|l|r|r|r|r|r|r|r|r|}
\hline \multicolumn{1}{|c|}{ Види риб ** і деякі промислові категорії } & \multicolumn{1}{|c|}{2006} & \multicolumn{1}{|c|}{2007} & 2008 & 2009 & 2010 & 2011 & 2012 & 2013 \\
\hline Лящ звичайний & 1280 & 1536 & 1768 & 1790 & 1689 & 1395 & 1601 & 1415 \\
\hline Плітка звичайна & 1406 & 1523 & 1479 & 1623 & 1508 & 1109 & 1490 & 1225 \\
\hline Білий та строкатий товстолобики & 340 & 536 & 461 & 246 & 236 & 61 & 75 & 41 \\
\hline Плоскирка звичайна & 333 & 427 & 302 & 393 & 372 & 333 & 390 & 334 \\
\hline Судак звичайний & 38 & 71 & 70 & 82 & 79 & 76 & 90 & 71 \\
\hline Карась сріблястий & 60 & 67 & 61 & 96 & 113 & 103 & 135 & 104 \\
\hline Синець звичайний & 59 & 56 & 49 & 62 & 57 & 24 & 33 & 35 \\
\hline Чехоня звичайна & 66 & 38 & 29 & 42 & 41 & 22 & 35 & 20 \\
\hline Окунь звичайний & 8 & 10 & 13 & 17 & 17 & 13 & 15 & 25 \\
\hline Короп звичайний & 6 & 7 & 7 & 16 & 28 & 13 & 20 & 9 \\
\hline Сом європейський & 2 & 6 & 12 & 18 & 21 & 19 & 31 & 27 \\
\hline Щука звичайна & 3 & 5 & 8 & 8 & 9 & 8 & 10 & 16 \\
\hline Білизна європейська & 3 & 2 & 2 & 6 & 7 & 6 & 6 & 3 \\
\hline В'язь європейсько-сибірський & 1 & - & - & 1 & 1 & 1 & 1 & 1 \\
\hline Інший крупний частик & - & - & - & - & 1 & - & - & - \\
\hline Інший дрібний частик & 1 & 1 & 1 & 1 & 3 & 2 & 1 & 4 \\
\hline $\begin{array}{l}\text { Верховодка звичайна та } \\
\text { тюлька чорноморсько-азовська }\end{array}$ & 62 & 26 & 14 & 77 & 117 & 93 & 112 & 68 \\
\hline \multicolumn{1}{|c|}{ Усього } & 3668 & 4311 & 4276 & 4478 & 4299 & 3278 & 4045 & 3398 \\
\hline
\end{tabular}

Примітки: *-вилов менше 1 т не врахований і округлений до тонни; ** - українські видові назви наведено за Моvсһап, 2011. 


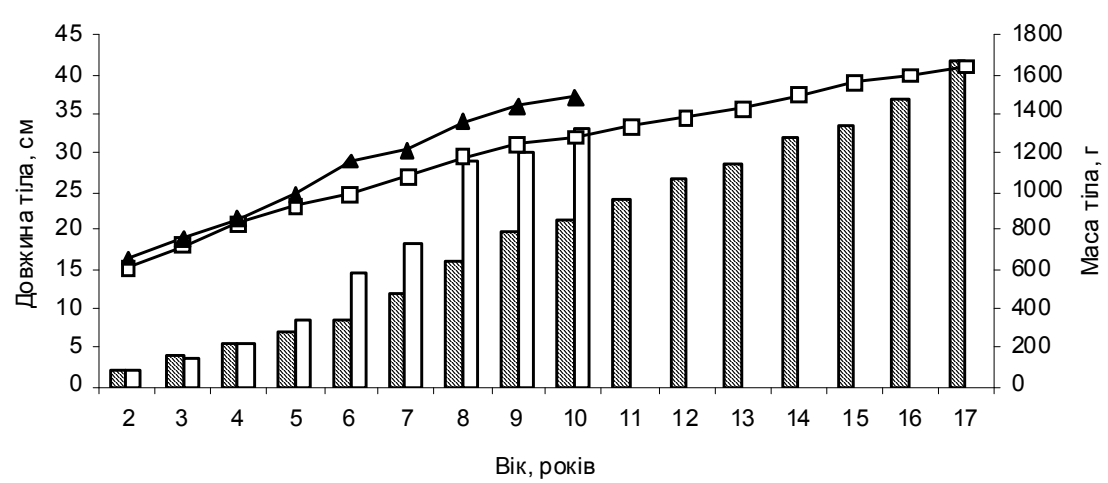

Рис. 2. Середня довжина та маса тіла окремих вікових груп $R$. rutilus

у Кременчуцькому водосховищі та природному заповіднику «Дніпровсько-Орільський»:

маса плітки Кременчуцького водосховища (прямокутники із косим штрихуванням) та природного заповідника «Дніпровсько-Орільський» (білі прямокутники); довжина плітки Кременчуцького водосховища (білі квадрати) та природного заповідника «Дніпровсько-Орільський» (чорні трикутники)

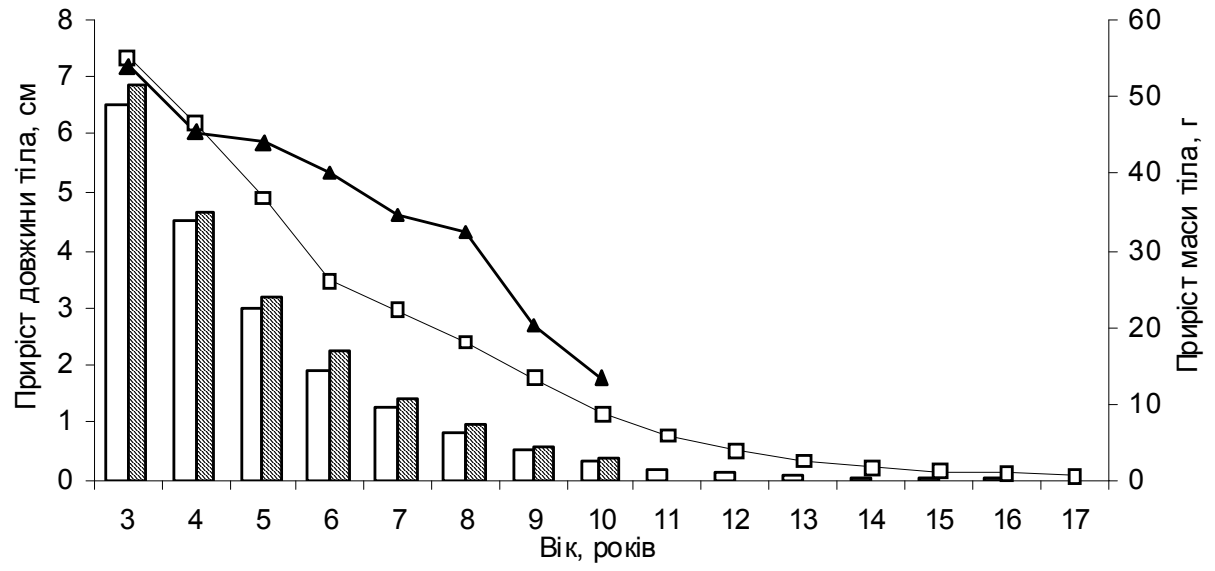

Рис. 3. Прирости довжини та маси тіла окремих вікових груп $R$. rutilus досліджуваних водойм: приріст довжини тіла плітки Кременчуцького водосховища (білі прямокутники) та природного заповідника «Дніпровсько-Орільський» (прямокутники із косим штрихуванням); приріст маси тіла плітки Кременчуцького водосховища (білі квадрати) та природного заповідника «Дніпровсько-Орільський» (чорні трикутники)

\section{Висновки}

Проаналізовано основні біологічні показники $R$. rutilus на ділянках Дніпра 3 різним рівнем промислового навантаження. Встановлено, що віковий ряд плітки на відкритому основному плесі Дніпра набагато більший, ніж у його придаткових річкових системах.

Розмірно-вагові показники вікових груп 6+ - 10+ у $R$. rutilus у водоймах з інтенсивним антропогенним навантаженням статистично достовірно нижчі, ніж у особин із природоохоронних акваторій. Це можна пояснити селективною дією промислу. На спрямовану елімінацію швидкоростучих особин також вказують криві приросту та час настання кульмінації приросту іхтіомаси.

Таким чином, на нашу думку, потужне антропогенне навантаження спричиняє накопичення тугорослих особин у популяції $R$. rutilus.

\section{Бібліографічні посилання}

Bondarev, D.L., 2006. Struktura nerestovoi' populjacii' plitky (Rutilus rutilus) vodojm Dniprovs'ko-Oril's'kogo pryrodnogo zapovidnyka [The structure of the spawning population of roach (Rutilus rutilus) in water bodies of the DniprovskoOrilskiy natural reserve]. Vìsn. Dnìpropetr. Unìv. Ser. Bìol. Ekol. 14(2), 20-24 (in Ukrainian).

EU intervention in inland fisheries, 2011. EU wide report - final version (Framework contract $\mathrm{N}^{\circ}$ FISH/2006/09). Ernst \& Young, www.ec.europa.eu/fisheries/documentation/studies/ inland_fisheries_en.pdf

Hayden, B., Massa-Gallucci, A., Harrod, C., O'grady, M., Caffrey, J., Kelly-Quinn, M. 2014. Trophic flexibility by roach Rutilus rutilus in novel habitats facilitates rapid growth and invasion success. J. Fish Biol. 84, 1099-1116.

Hellawell, J.M., 1972. The growth, reproduction and food of the roach Rutilus rutilus (L.), of the River Lugg, Herefordshire. J. Fish Biol. 4, 469-486.

Hickley, P., Dexter, K.F., 1979. A comparative index for quantifying growth in length of fish. Fish. Manage. 10(4), 147-151.

Kotovska, G.O., Rudyk-Leusska, N.Y., Khristenko, D.S., 2012. Porivnyannya produktyvnyh kharakterystyk molodi plitky (Rutilus rutilus L.) v Sulynskiy i Tsybulnytskiy zatokah Kremenchutskogo vodoshovyscha [Comparison of productive characteristics of young raoch (Rutilus rutilus L.) in Sula and Tsybulnyk bays of Kremenchug reservoir]. Bioresursy i Pryrodokorystuvannja 4(1), 101-104 (in Ukrainian).

Kottelat, M., Freyhof, J., 2007. Handbook of European freshwater fishes. Publications Kottelat, Cornol, Switzerland.

Lammens, E.H., van Nes, E.H., Meijer, M.L., van den Berg, M.S., 2004. Effects of commercial fishery on the bream 
population and the expansion of Chara aspera in Lake Veluwe. Ecol. Model. 177(3), 233-244.

Mann, R.H.K., 1973. Observations on the age, growth, reproduction and food of the roach Rutilus rutilus (L.) in two rivers in southern England. J. Fish Biol. 5, 707-736.

Movchan, Y.V., 2011. Ryby Ukrainy (vyznachnyk-dovidnyk) [Fish of Ukraine (Identification guide)]. Zoloti Vorota, Kyiv (in Ukrainian).

Nazarov, O.B., Kotovska, G.O., 2012. Osnovni biologichni pokaznyky plitky (Rutilus rutilus L.) Dniprodzerzhynskogo vodoshovyscha [Basic biological indicators o the roach (Rutilus rutilus L.) of Dniprodzerzhynsk reservoir. Fisheries Science of Ukraine 3-4, 80-83 (in Ukrainian).

Novitskiy, R.A., 2004. K voprosy o maksimalnyh razmerah i masse ryb $\mathrm{v}$ dneprovskih vodohranilisch [On the question of the maximum size and weight of the fish in the Dnieper reservoirs]. Vìsn. Dnìpropetr. Unìv. Ser. Bìol. Ekol. 12(1), 126-133 (in Russian).

Novitskiy, R.A., Yarovoy, A.G., 2000. Ulovy rybolovov Pridneprovja [Catches of anglers in the Dnieper region]. Rybnoe Hozjajstvo Ukrainy 5, 46-48 (in Russian).

Ozinkovska, S.P. (ed.), 1998. Metodyka zbory i obrobky ihtiologichnyh i hydrobiologichnyh materialiv $\mathrm{z}$ metoyu vyznachennya limitiv promyslovogo vyluchennya ryb $z$ velykyh vodoshovysch i lymaniv Ukrainy [Methods of collecting and processing of ichthyological and hydrobiological materials in order to identify limits of commercial fish harvest from large reservoirs and estuaries of Ukraine]. Institute of Fisheries of NAAS of Ukraine, Kyiv (in Ukrainian).

Ozinkovska, S.P., Khrystenko, D.S., Kotovska, G.O., 2006. Dynamika vylovu osnovnyh promyslovyh vydiv ryb na Kremenchuc'komu ta Kahovs'komu vodoshovyshhah [Catch dynamics of the main commercial fish species in the Kremenchug and Kakhovka reservoirs]. Naukovyj Visnyk NAU 102, 61-67 (in Ukrainian).

Pakhomov, O.Y., Gasso, V.Y., Goloborodko, K.K., Poljakov, M.V., Grycan, Y.I., Bulakhov, V.L., Brygadyrenko, V.V., Kljuchko, Z.F., Mezhzherin, S.V., Novicky, R.O., Pysanec, Y.M., Pljushh, I.G., Ponomarenko, O.L., Puchkov, O.V.,
Radchenko, V.G., 2011. Chervona knyga Dnipropetrovskoi oblasti. Tvarynnyj svit [The red book of Dnipropetrovsk region. Animals]. New Print, Dnipropetrovsk (in Ukrainian).

Pakhorukov, A.M., 1980. Izuchenie raspredeleniya molodi ryb v vodohranilischah i ozerah [The study of the juvenile fish distribution in reservoirs and lakes]. Nauka, Moscow (in Russian).

Pravdin, I.F., 1966. Rukovodstvo po izucheniyu ryb [Guidance on fish investigations]. Pischevaya Promyshlennost', Moscow (in Russian).

Przybylski, M., 1996. Variation in fish growth characteristics along a river cours. Hydrobiologia 325, 39-46.

Romanenko, V.D. (ed.), 2006. Metody hydroekologichnyh doslidzhen' poverhnevyh vod [Methods of hydroecological surveying of surface waters]. Logos, Kyiv (in Ukrainian).

Rudyk-Leusska, N.Y., Kotovska, G.O., Khristenko, D.S., 2011. Porivyalnyj analiz populyatsij plitky zvychaynoyi (Rutilus rutilus L.) Kremenchutskogo ta Kyivs'kogo vodoshovysch [Comparative analysis of common roach (Rutilus rutilus L.) populations in Kremenchug and Kiev reservoirs]. Naukovi dopovidi NUBiP 5(27), 1-9 (in Ukrainian).

Spesivyj, T.V., 2004. Sravnitelnye dannye morfologicheskih priznakov populyazij plotvy (Rutilus rutilus L.) Kakhovskogo i Kremenchugskogo vodochranilisch [Comparative data on morphological characters of roach (Rutilus rutilus L.) populations of Kakhovka and Kremenchug reservoirs]. Rybne Gospodarstvo 63, 211-214 (in Russian).

Stoessel, D.J. 2014. Age, growth, condition and reproduction of roach Rutilus rutilus (Teleostei: Cyprinidae), in southeastern Australia. Mar. Freshwater Res. 65, 275-281.

Tribiloustova, E., 2005. Freshwater fish for European Markets Globefish Research Programme. www.globefish.org/upl/ Publications/files/GRP\%2082.pdf

Vyatchanina, L.I., 1973. Biologicheskie osobennosti plotvy Kremenchugskogo vodochranilischa i eje rybohozyaistvennoe znachenie [Biological features of roach of the Kremenchug Reservoir and its fishery value]. Rybnoe Hozjajstvo 16, 71-76 (in Russian).

Надійшла до редколегї 24.07.2015 